\title{
MERCURY REDUCTASE ACTIVITY OF AN INDIGENOUS MERCURY RESISTANT BACTERIAL ISOLATE (Bacillus sp. S1) FROM KALIMAS-SURABAYA AS A POTENTIAL REDUCING AGENT FOR MERCURIAL ION $\left(\mathrm{HG}^{2+}\right)$
}

\author{
Enny Zulaika ${ }^{1 * *}$ and Langkah Sembiring ${ }^{2}$ \\ 1 Jurusan Biologi-FMIPA, Institut Teknologi Sepuluh Nopember, Surabaya \\ ${ }^{2}$ Laboratorium Mikrobiologi, Fakultas Biologi, Universitas Gadjah Mada, Yogyakarta \\ **enny@bio.its.ac.id
}

\begin{abstract}
Mercury reductase activity and $\mathrm{Hg}^{2+}$ lowering capacity of a Mercury Resistant Bacteria (MRB) (Bacillus sp. S1) which was isolated from Kalimas River of Surabaya, Indonesia were studied. The activity was determined by Mercury Reductase Assay System (MRAS) in a solution mixture contained $50 \mathrm{mM} \mathrm{PBS}(\mathrm{pH} \pm 7.0), 0.5$ mM EDTA, $200 \mu \mathrm{M} \mathrm{MgSO} 4,0.1 \%(\mathrm{v} / \mathrm{v})$ B-merchaptoethanol, $200 \mu \mathrm{M} \mathrm{NADH} 2$ and $25 \mathrm{mg} / \mathrm{L} \mathrm{HgCl}$ and one volume of crude extract incubated at room temperature for various interval period of time. Mercury reductase activity was measured spectrophotometrically at $340 \mathrm{~nm}$. One unit of reductase activity was defined as one molar of oxidized $\mathrm{NADH}_{2}$ produced per total cell per minute. Results of study showed that, the isolate could resist the concentration of $\mathrm{HgCl}_{2}$ up to $11 \mathrm{mg} / \mathrm{L}$. At 30 minute incubation period at room temperature, the highest mercury reductase activity and the $\mathrm{Hg}^{2+}$ lowering capacity was found to be 0.006 unit/109cell and $1.48 \mathrm{mg} / \mathrm{L} / 109$ cell/minute, respectively with the reduction efficiency of $\mathrm{Hg}^{2+}$ to $\mathrm{Hg}^{0}$ of $0.18 \%$ per minute. Therefore, it can be concluded that the Bacillus sp. S1 isolate could be assumed to be exellent mercury bioremediation agent since it was found to be highly mercury resistant and very efficient to reduce cationic mercury $\left(\mathrm{Hg}^{2+}\right)$ to elemental mercury $\left(\mathrm{Hg}^{0}\right)$.
\end{abstract}

Key words: Kalimas-Surabaya, Bacillus sp. S1, Mercury resistant, Mercury reductase

\section{INTRODUCTION}

Kalimas River in Surabaya, East Java province of Indonesia has been contaminated by mercury as indicated by the measured levels of mercury of $6.3 \mathrm{mg} / \mathrm{Kg}$ in the samples taken from downstream sediments of the river (Zulaika et al., 2012). The phenomenon was very worrying because mercury may cause neurotoxic effects on humans. However, in natural habitats, there are bacteria that might be able to resist mercury which are known as Mercury Resistant Bacteria (MRB). Such bacteria, possess enzymatic mechanism to reduce divalent mercury $\left(\mathrm{Hg}^{2+}\right)$ into volatile mercury of $\mathrm{Hg}^{0}$ (Nascimento \& Chartone-Souza, 2003) due to their possession of mercury resistant gene known as mer-operon, and merA is one of mer-operon groups that code for mercury reductase (Kiyono \& Pan-Hou, 2006.). Usually, mer-operon gene is located within plasmid or transposon (Davis et al., 2005). Plasmid is likely to carry a certain gene or more that might code for some special characters in bacteria, such as resistance and viability to antibiotics and heavy metals (Nithya et al., 2011).

Mercury reductase is an oxydoreductase which involves $\mathrm{NADPH}_{2}$ or $\mathrm{NADH}_{2}$ coenzyme in catalyzing electron replacement (Murray, 1996). As an electron source in oxidation-reduction process, $\mathrm{NADH}_{2}$ or $\mathrm{NADPH}_{2}$ are involved to change $\mathrm{Hg}^{2+}$ to be volatile $\mathrm{Hg}^{0}$ or vice versa (Zeroual et al., 2003). The efficiency rate of changing $\mathrm{Hg}^{2+}$ to be volatile $\mathrm{Hg}^{0}$ by Pseudomonas putida SP-1 MRB was reported to be $89 \%$ (Zhang et al., 2012) whereas Hydrogenivirga sp. 379128 R1-1 was reported to reduce 150 imole Hg${ }^{2+} / 10^{6}$ cell/hour (Freed- 
man et al., 2012). A bacterial isolate belong to the genus Bacillus isolated from KalimasSurabaya was found to be dominant among the MRB isolates, and Bacillus sp. S1 was one of them which was highly resistant to $\mathrm{HgCl}_{2}$ concentration of $11 \mathrm{mg} / \mathrm{L}$ (Zulaika., 2013). This research aimed at measuring mercury reductase activity as well as $\mathrm{Hg}^{2+}$ lowering capacity of Bacillus sp. S1 as an indigenous MRB isolate from Kalimas-Surabaya Indonesia.

\section{MATERIALS AND METHODS}

\section{Preparation of enzyme extracts}

After 12 hour of incubation periods of culture, the culture of Bacillus sp. S1 was harvested by centrifugation at $15000 \mathrm{rpm}$ for 20 minute at $4^{\circ} \mathrm{C}$. Crude cell extract was re-suspended in $30 \mathrm{ml}$ Phospate Buffer Saline (PBS), $\mathrm{pH} \pm 7.0$. Cells were then disrupted by sonication with ultrasonic processor at 600 watt and $50 \%$ amplitude for 60 seconds, and the resultant homogenate was centrifuged at $15000 \mathrm{rpm}$ for 30 minute at $4^{\circ} \mathrm{C}$. The supernatant was collected as crude enzyme extract and then removed into black and dark vial tube (Ogunseitan, 1998) to be used in further experiments.

\section{Mercury Reductase Assay System (MRAS)}

Mercury reductase activity was measured in a Mercury Reductase Assay System (MRAS) solution in dark tube contained $50 \mathrm{mM}$ PBS $(\mathrm{pH} \pm 7.0), 0.5 \mathrm{mM}$ EDTA, 200 ì $\mathrm{MgSO}_{4}, 0.1 \%$ (v/v) B-merchaptoethanol, $200 \mathrm{iM} \mathrm{NADH}_{2}$ and $25 \mathrm{mg} / \mathrm{L} \mathrm{HgCl}$ (Ogunseitan, 1998). One volume of crude extract was added into MRAS solution and incubated at room temperature for various interval durationof 30, 60, 90, 120 and 150 minutes. Mercury reductase activity was measured spectrophotometrically at $340 \mathrm{~nm}$ (Takeuchi et al., 1999). A one unit of mercury reductase activity was defined as one molar of oxidized $\mathrm{NADH}_{2}$ produced per total cell per minute in the assay condition (Zeroual et al., 2003).

\section{RESULTS AND DISCUSSION}

The MRB isolate was identified to be member of the genus Bacillus and named as Bacillus sp. S1 based on key characters (Holt et al., 1994) which were rod cell shape, gram positive, motile, forming endospore, aerobes, chemo-organotroph and catalase positive. (Table 1).

Table 1. Identification of Bacillus sp. S1 characters based on key characters of the genus Bacillus

\begin{tabular}{|c|c|c|c|}
\hline No & Characters & Genus Bacillus & Bacillus sp. S1 \\
\hline 1 & Road & + & + \\
\hline 2 & Gram & + & + \\
\hline 3 & Motility & + & + \\
\hline 4 & Endospore & + & + \\
\hline 5 & Aerobes/ facultative anaerobes & $+/+$ & $+1-$ \\
\hline 6 & Chemoorganotroph & + & + \\
\hline 7 & Catalase & + & + \\
\hline
\end{tabular}

The genus Bacillus contains 18 sub-groups which form endospore, gram positive, and road cell shape (Holt et al. (1994). According to Maughan dan Auwera (2011), member of the genus Bacillus has abundant number in nature. Those strains are very adaptive to 
environments by means of character variation. They might be antagonistic, synergistic, pathogenic or even beneficial. Certain Bacillus strains could produce antibiotic, insecticide, hence they could be used as bioremediation agent. Another Bacillus strain member may be tolerant to higher osmotic pressure. Their optimum growth temperature is around $30-45^{\circ} \mathrm{C}$ (mesophilic).

Bacillus sp. S1 isolate was found to be tolerant to antibiotic, such as ampicillin, tetracycline and chloramphenicol (Zulaika et al., 2012), indicated that Bacillus sp. S1 contained a plasmid. In MRB, it has been clear that plasmid codes for one amongst genes coding for heavy metal resistance, and merA is the gene which codes for mercury reductase and therefore they are resistant to mercury and able to reduce $\mathrm{Hg}^{2+}$ into $\mathrm{Hg}^{\circ}$ (Kiyono \& Pan-Hou, 2006). Mercury reductase activity of Bacillus sp. $S 1$ isolate in various incubation period is shown in Table 2.

Table 2. Mercury reductase enzyme activity, oxidized NADH and reduced $\mathrm{Hg}^{2+}$

\begin{tabular}{|c|c|c|c|c|}
\hline $\begin{array}{c}\text { Periods } \\
\text { (minutes) } \\
*\end{array}$ & $\begin{array}{l}\text { Enzyme activity } \\
\text { (unit } / 10^{9} \text { cell) }\end{array}$ & $\begin{array}{c}\text { Oxidized NADH } \\
\text { ( } \mu \mathrm{M} / 10^{9} \mathrm{cell} \\
\text { /minute })\end{array}$ & $\begin{array}{c}\text { Reduction of } \\
\mathrm{Hg}^{2+} * \\
\text { (mg/L/10 } / 10^{9} \mathrm{cell} \\
\text { /minute) }\end{array}$ & $\begin{array}{c}\% \text { Reduction } \\
\text { of } \mathrm{Hg}^{2+} \\
\text { /minute }\end{array}$ \\
\hline 30 & $0.0060 \pm 0,0003$ & $0.179 \pm 0,028$ & $1.480^{a} \pm 0,19$ & 0.18 \\
\hline 60 & $0.0033 \pm 0,0002$ & $0.146 \pm 0,023$ & $0.487^{b} \pm 0,08$ & 0.12 \\
\hline 90 & $0.0023 \pm 0,0001$ & $0.109 \pm 0,018$ & $0.243^{c} \pm 0,04$ & 0.09 \\
\hline 120 & $0.0019 \pm 0,0003$ & $0.100 \pm 0,030$ & $0.167^{d} \pm 0,05$ & 0.08 \\
\hline 150 & $0.0016 \pm 0,0002$ & $0.087 \pm 0,025$ & $0.117^{e} \pm 0,03$ & 0.07 \\
\hline
\end{tabular}

Based on Table 2, the highest mercury reductase activity appeared to be at 30 minute incubation period which was 0.0060 unit $/ 10^{\circ}$ cell either expressed as oxidized $\mathrm{NADH}_{2}$ amount $0.221 \mu \mathrm{M} / 10^{9} \mathrm{sel} /$ minute or as the amount of reduced $\mathrm{Hg}^{2+} 1.480 \mathrm{mg} / \mathrm{L} / 10^{9} \mathrm{sel} /$ minute as shown in Figure 1. This might be due to the fact that the longer the incubation period, the lower substrate availability and the less intact enzyme quantity, and therefore autaomatically decreased the oxidized $\mathrm{NADH}_{2}$ production as well as lowered the $\mathrm{Hg}^{2+}$ reduction.

Bacillus sp. S1 as MRB was isolated from downstream of Kalimas River of Surabaya with $6.3 \mathrm{mg} / \mathrm{Kg}$ level of mercury (Zulaika et al., 2012) hence it was ecpected that it could adapt to survive in medium containing mercury. It was reported that indigenous MRB isolate from contaminated mercury area were found to be much more adaptive to $\mathrm{Hg}^{2+}$ than the isolate originated from incontaminated area due to its effectiveness in reducing $\mathrm{Hg}^{2+}$ (Ghoshal et al., 2011). Therefore, the isolate of Bacillus sp. S1 could be expected to be very potential to be used as mercury bioremediation agent. This isolate was exellent in terms of mercury reductase enzyme productivity, and capacity to reduce $\mathrm{Hg}^{2+}$ to $\mathrm{Hg}^{\circ}$ by means of oxidation of $\mathrm{NADH}_{2}$. The isolate could resist the concentration of $\mathrm{HgCl}_{2}$ up to $11 \mathrm{mg} / \mathrm{L}$. The highest mercury reductase enzyme activity $\left(0.006\right.$ unit $\left./ 10^{9} \mathrm{cell}\right)$ and the $\mathrm{Hg}^{2+}$ lowering capacity of 1.48 $\mathrm{mg} / \mathrm{L} / 10^{9} \mathrm{Cell} /$ minute with $0.18 \%$ per minute reduction efficiency of $\mathrm{Hg}^{2+}$ to $\mathrm{Hg}^{0}$ was observed at 30 minute incubation period at room temperature. 


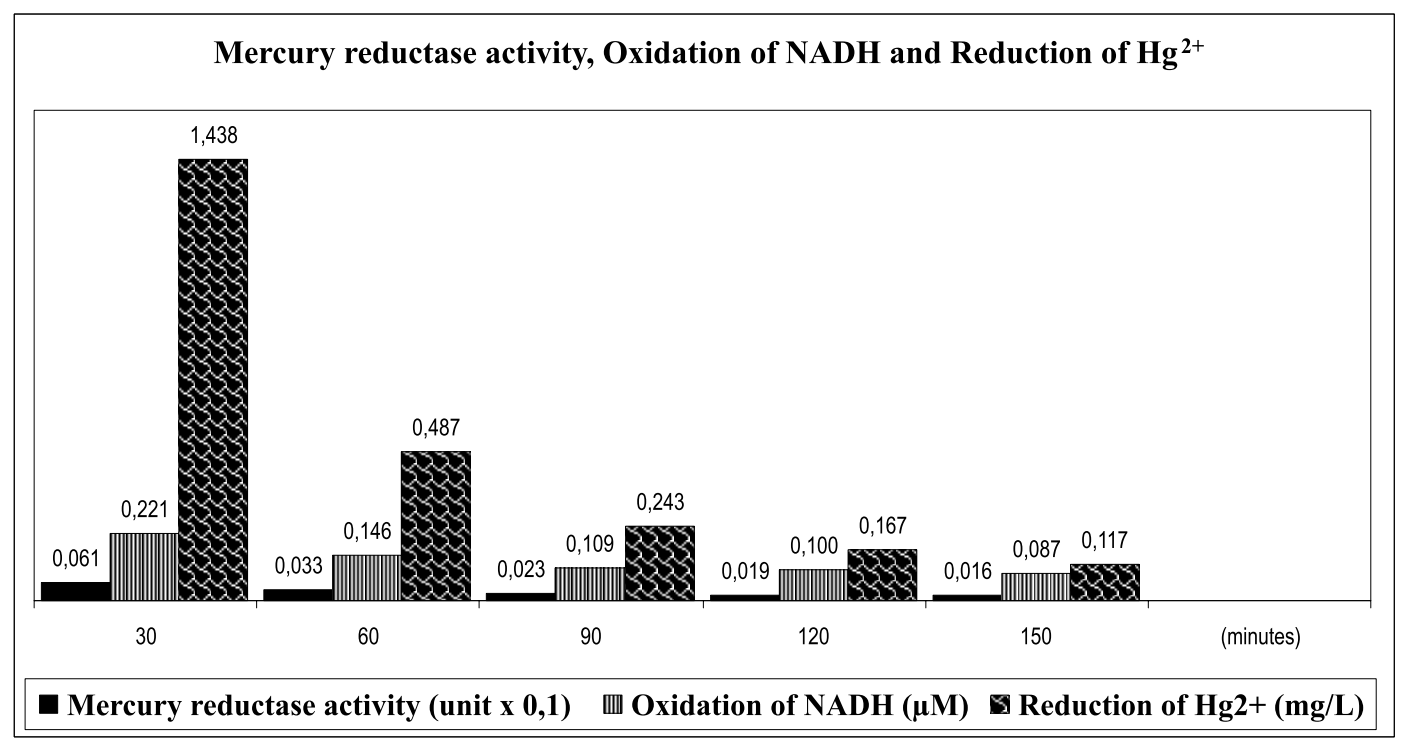

Figure 1. Mercury reductase activity (unit $x 0,1$ ), Oxidation of $\mathrm{NADH}_{2}(\mu \mathrm{M})$ and Reduction of $\mathrm{Hg}^{2+}\left(\mathrm{mg} / \mathrm{L} / 10^{9} \mathrm{cell} /\right.$ minute) by Bacillus sp. $\mathrm{S} 1$ isolate.

\section{CONCLUSION}

Bacillus sp. S1 isolate could be assumed to be exellent mercury bioremediation agent since it was found to be highly mercury resistant. The isolate could resist the concentration of $\mathrm{HgCl}_{2}$ up to $11 \mathrm{mg} / \mathrm{L}$. At 30 minute incubation period at room temperature, the highest mercury reductase activity and the $\mathrm{Hg}^{2+}$ lowering capacity was found to be 0.006 unit/10 ${ }^{9} \mathrm{cell}$ and $1.48 \mathrm{mg} / \mathrm{L} / 10^{9} \mathrm{cell} /$ minute, respectively with the reduction efficiency of $\mathrm{Hg}^{2+}$ to $\mathrm{Hg}^{0}$ of $0.18 \%$ per minute.

\section{REFERENCES}

Davis, I.J., A.P. Robert, D. Ready, H. Richards, M. Wilson, and P. Mullany. 2005. Linkage of a Novel Mercury Resistance Operon with Streptomycin Resistance on a Conjugative Plasmid in Enterococcus faecium. Plasmid, 54: 26 - 38.

Freedman, Z., C. Zhu, and T. Barkay. 2012. Mercury Resistance, Mercuric Reductase Activities and Expression Among Chemotrophic Thermophilic Aquificae. Applied Environmental Microbiology, 10: 1-34.

Ghoshal, S., P. Bhattacharya, and R. Chowdhury. 2011. De-mercurization of Wastewater by Bacillus cereus (JUBT1): Growth Kinetics, Biofilm Reactor Study and Field Emission Scanning Electron Microscopic Analysis. Journal of Hazardous Materials, 194: 355 361.

Holt, J.G., N.R. Krieg, H.A. Sneath, J.T. Staley, and S.T. Wiliam. 1994. Bergey's Manual of Determinative Bacteriology $9^{\text {th }}$ Ed, William \& Wilkins, Baltimore.

Kiyono, M., and H. Pan-Hou. 2006. Genetic Enginering of Bacteria for Environmental Remediation of Mercury. Journal of Health Science, 52 (3): 199 - 204.

Maughan, H., and G.V. Auwera. 2011. Bacillus Taxonomy in The Genomic Era Finds Phenotypes to be Essential Though Often Misleading. Infection, Genetics and Evolution, 11: 789 - 797.

Murray, M. 1996. The Encyclopaedia of Nutritional Supplements. P. 44-53 
Nascimento, A.M.A., and E. Charton-Souza. 2003. Operon mer. Bacterial Resistance to Mercury and Potential for Bioremediation of Contamined Environments. Journal Genetics and Molecular Research, 2(1): 92 - 101.

Nithya, C., B. Gnanalakshmi, and .K. Pandian. 2011. Assessment and Characterization of Heavy Metal Resistance in Palk Bay Sediment Bacteria. Marine Environmental Research, 71: 283 - 294.

Ogunseitan, O.A. 1998. Protein Method for Investigating Mercuric Reductase Gene Expression in Aquatic Environments. Applied Environmental Microbiology, 64(2): 695702.

Takeuchi, F., K. Iwahori, T. Maeda, K. Kamimura, and T. Sugio. 1999. Isolation and Some Properties of the Ferrooxidans Strains with Differing Levels of Mercury Resistance from Natural Environments. Journal of Bioscience and Bioenginnering, 88(4): 387 - 392.

Zeroual, Y. A., F.Z. Moutaouakkil, M. Dzairi, P.U. Talbi, K.L. Chung, and M. Blaghen. 2003. Purification and Characterization of Cytosolic Mercuric Reductase from Klebsiella pneumonia. Annals of Microbiology, 53: 149 -160.

Zhang, W., L. Chen, and D. Liu. 2012. Characterization of a marine-isolated Mercuryresistant Pseudomonas putida strain SP1 and its potential application in marine Mercury reduction. Applied Microbiology and Biotechnology. 93: 1305-1314.

Zulaika, E., L. Sembiring, and A. Soegianto. 2012. Characterization and dentification of Mercury-resistant Bacteria from Kalimas River Surabaya-Indonesia by Numerical Phenetic Taxonomy. Journal Basic Applied Science Research, 2(7): 7263 - 7269.

Zulaika, E., 2013. The Exploration of Indigenous Mercury-Resistant Bacteria in Kalimas, Surabaya as an Agent of Bioremediation of Mercury Pollution. Disertasi. Fakultas Sains \& Teknologi. Airlangga University, Surabaya. 